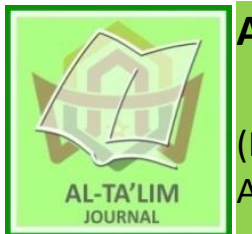

AL-TA'LIM JOURNAL, 25 (2), 2018, (128-134)

(Print ISSN 1410-7546 Online ISSN 2355-7893)

Available online at http://journal.tarbiyahiainib.ac.id/index.php/attalim

\title{
Blog Folio in Blended Learning: a Development of Students' Information Processing Skills in Digital Age
}

\author{
Received: $11^{\text {th }}$ January 2018; Revised: 12 ${ }^{\text {th }}$ April 2018; Accepted: $28^{\text {th }}$ July 2018 \\ Permalink/DOI: http://dx.doi.org/10.15548/it.v25i2.369
}

\section{Ulfia Rahmi *)}

Universitas Negeri Padang, Indonesia.

E-Mail: ulfia@fip.unp.ac.id

\section{Deni Darmawan}

Universitas Pendidikan Indonesia,

Bandung, Indonesia.

E-Mail: denidarmawan@upi.edu

\section{*) Corresponding Author}

\begin{abstract}
Paradigm shift in educational context support to instructional innovation, such as online learning, blended learning, and mobile learning. Researcher implemented the blended learning by using blog as portfolios for students. The purpose in this research was to identify the effects of using a blog in blended learning to improve collage student's information processing skill in virtual environment. The facilitation given to college students in order to familiar with through search, collect, manages, and communicates information in digital age. Research subject is collage students in Development of Innovation Instructional Model course on period January-June 2017 at Educational Technology in Universitas Negeri Padang. This research used three instruments, consist of 1) the rubrics for identify information processing skill, 2) questionnaire for using blog folio, and 3) interview guided about advantages, challenges and obstacles to use a blog in blended learning. The result show that using blog folio can help collage students to improved information processing skills because they understood and tried the steps of that skill. Furthermore, they admitted by using blog folio can increased motivation, participation and give advantages.
\end{abstract}

Keywords: Blog folio; blended learning; information processing

How to Cite: Rahmi, U., \& Darmawan, D. (2018). Blog folio in blended learning: A development of students' information processing skills in digital age. Al-Ta Lim Journal, 25(2). doi: http://dx.doi.org/10.15548/jt.v25i2.369

\section{INTRODUCTION}

Most teachers want to improve their professional practice in the classroom (Desimone, 2009; Feiman-Nemser, 2003; Guskey, 2002b, 2002a; Jacobs, 2010). Currently, most of instructional process optimized the use of computer and technology. The advances in technology offer flexibility and accessibility, as a result instructional process can do anywhere and anytime. The internet offers resources for learning anytime/anywhere which allows extensive flexibility in learning processes (Fullwood, Sheehan, \& Nicholls, 2009; Goktas \& Demirel, 2012; Kuo, Belland, \&
Kuo, 2017; Papastergiou, Gerodimos, \& Antoniou, 2011; Põldoja \& Laanpere, 2014). Lecturer and college student can integrate computer and internet in the class. They can create instructional interaction without attending to the class because they are connected by internet. Learning in classroom transformed to virtual class, hybrid, blended and lately personal learning environment and the blended learning got the highest satisfaction score (Curran, Sharpe, Forristall, \& Flynn, 2008; Dziuban, Moskal, \& Hartman, 2005; Woltering, Herrler, Spitzer, \& Spreckelsen, 2009). These conveniences make the possibilities for lecturer in creating the innovative instructional design. The 
implication is we need to transform our learning systems to equip students with the knowledge and skills they will need to succeed in this new global era (Brooks, Nolan, \& Gallagher, 2006; Land \& Greene, 2000).

Researcher concentrated on application of blended learning in order to innovate of instruction since 2012. This research applied the blog folios in blended learning. Blended learning is an instruction that combines face-to-face with online learning. Online learning involves network in instruction (Inan \& Lowther, 2010; Sari, 2014; Smaldino, Lowther, Russell, \& Mims, 2008) intranet or internet. In this researcher, the utilization of this blended learning using media that called blog. Li, Bado, Smith, \& Moore (2013) says blog give similar characteristic with website but blog is more easy to update since it has platform which makes it easy for user to maintenance their blog. Blog in instruction can be function as eportfolio or digital portfolio or blog folios for students. Digital portfolios represent a powerful way to a collect student work Niguidula (2010), because the student can posting text, graphic, and multimedia components in a blog (Bullock \& Hawk, 2001; Gatlin \& Jacob, 2002; Hartnell-Young \& Morriss, 1999; Niguidula, 2010; Wall, Higgins, Miller, \& Packard, 2006). The student's posting in a blog that call by digital portfolio is a multimedia collection of student work that provides evidence of a student's skills and knowledge (Niguidula, 2010). The use of application of blog folio in this research becomes students' weekly reading report that is suitable with syllabus. The students are introduced with how to process information in digital era. They need to understand how to process the information in digital era since they will be flood of information.

There are four stages to identify the problem of college student to process the information, such as 1) input as a process to record of information, 2) integration as a translate processing, information categories, and appreciate information, 3) output as a action including language and attitudes, and 4) identify the problems of instructional about the advantages and disadvantages of previous three aspects (Pritchard, 2013). Tur \& Urbina (2014) explain that a blog can be to building network between early childhoods in the future.

The teachers' candidate needs to be familiar with the use of technology, because they will face digital generation, including the teacher in elementary school, middle school, and higher education. The result of research's Goktas \& Demirel (2012) found that using receive a blog as an important tool to familiarize the use technology. Some of the skills, such as communication, independent learning, attitudes, and responsibilities, cooperative and flexibilities, digital skill, digital and knowledge management are necessary skills in digital age (Beetham \& Sharpe, 2013; Collis \& Moonen, 2012; Duzenli, 2018; Rose, Meyer, Strangman, \& Rappolt, 2002). All of the skills are summarized in the information processing step. Related to that, the use of blog in blended learning environment is to improve information processing capability in digital era

The use of blogs in blended learning is considered relevant to equip information processing skills because students need to be given the opportunity to do it themselves. Information processing theory recognizes an individual's cognitive ability to use information actively when engaged with learning tasks (Mayer \& Alexander, 2016). Students construction their knowledge through interpretation of the experience they get (Harasim, 2012).

The experiences of finding, processing and conveying information through blogs teach them how to process information. It is important for students to have these abilities because they are in the digital era. Therefore, lecturer in blended learning environment needs to provide and consider online learning tools to encourage students to work more in processing information. One of the forms through learning activities that is authentic 
and interactive such as posting a weekly reading.

The posting can be read and commented on by other students. At the time of interaction between students in the blog, includes in it meaning full learning and constructivist learning. According to Pritchard (2009) activities or tasks that are authentic tend to attract students' attention and interest so that their involvement is higher than less authentic learning. However, in fact there are still many students who have not understood and have the ability to process information because data found that students tend to receive directly the information they receive without comparison with other information and confirm the truth of the information.

The problem is getting worse when students are not familiar with the use of technology. Essentially, the use of technology facilitates anyone in self-study, including understanding how to process information in the digital age. Inability to process information correctly and less familiar with technology resulted in many technology users spreading half or even incorrect information. Researchers use blog folios in a blended learning environment.

Students are accustomed to collect, process, and convey information through their respective blogs in accordance with the demands of the syllabus. Researchers analyze the processes and developments that occur to assess the impact of the use of blog folios in blended learning as an effort to improve their information processing skill in a virtual environment.

\section{METHOD}

This type of research is a mixed method, combining qualitative and quantitative data. This type of research is relevant to know the level of contribution of blog usage as e-portfolio in blended learning. This research explores information both ways to obtain more accurate and meaningful information. This research procedure includes applying the use of blog by student as e- portfolio. Every student has a blog because it becomes the objective of e-learning courses in the previous semester. The blog in Development of Innovative Learning Model courses serve as a means of reporting the results of the reading each week in accordance with the subject contained in the syllabus. During seven meetings, students are provided with concepts and they report the reading before coming to class for face-toface meetings. After that, the purpose of the next meeting of students reports the progress of their work according to the development model in fulfilling the final objectives of the lecture.

The object of research is blog folio and information processing. Quantitative data in this study were obtained using the instrument, namely 1) assessment rubric to see the ability to collect / process / convey information based on virtual, 2) questionnaire of student response to the use of blog folios and 3) guide interview about the advantages, challenges and barriers to use blog in blended learning. The use of blogs is of course related to the processing of information that occurs during the use of blogs in a blended learning environment.

The indicators consist of 1) information processing including selection, sequencing, summary, and synthesis, and 2) blog usage includes motivation, liveliness and benefits. The sample technique used is total sampling because the instrument is given to all students who are active in Innovative Learning Model section 201620040008.

The number of students is 42 students. While the source of data qualitatively in this study obtained through observations and interviews about the use of blogs in the environment blended learning and benefits blog for students in processing information in the digital era.

Data collection using interview guides and observation guides conducted by snowball sampling. Data analysis technique used in this research is descriptive data analysis technique. Quantitative data is 
analyzed per indicator and sub indicator, while the qualitative data helps to interpret the result obtained through the quantitative instrument.

\section{RESULT AND DISCUSSION}

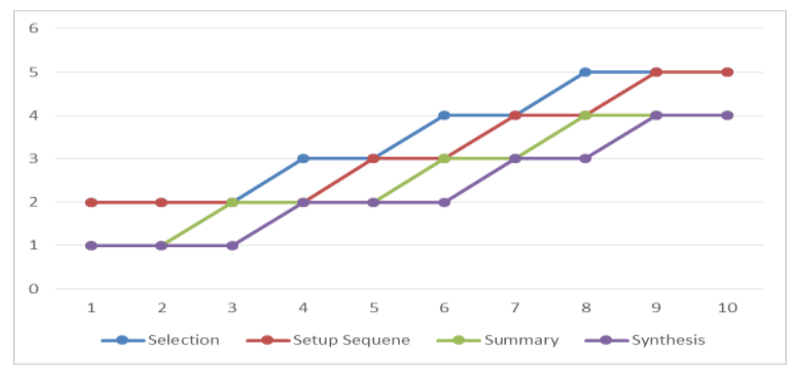

Figure 1. Development of Student Information Processing Capability through Blog folios Usage in Blended Learning

There are 38 active blog folios during the research process. It means $90.5 \%$ of students consistently improve the content on their blogs. The rest, about $9.5 \%$ did not give his blog address to lecturers. Based on the scoring rubric used, it obtained data that there are changes and developments of the information for students. From initially using only one reference, it developed into the essence of various references. The development of students' information processing capability is recorded using the scoring rubric; the result can be seen in Figure 1. Furthermore, based on the questionnaire distributed, the stage of selecting information processing by students was excavated with four qu0xestions. The results can be seen in table 1 .
Table 1. Information Processing Stages by Students

\begin{tabular}{lcc}
\hline \multicolumn{1}{c}{ Selection } & $\begin{array}{c}\text { The } \\
\text { Number of }\end{array}$ & $\%$ \\
\hline $\begin{array}{l}\text { References from Books } \\
\text { Internet source }\end{array}$ & 88 & 50,2857 \\
$\begin{array}{l}\text { Difficulty choosing } \\
\text { material }\end{array}$ & 103 & 58,8571 \\
Syllabus as a guide & 138 & 78,8571 \\
\multicolumn{2}{c}{ Setup Sequence } & \\
Ability to organize & 163 & 93,1429 \\
Based on references read & 131 & 74,8571 \\
Syllabus as a guide & 137 & 78,2857 \\
\end{tabular}

Table 1 informs that students choose content or information based on course syllabus demands. At the beginning of using blog folio, students have trouble in choosing the material. They use more resources from the internet than using references from books. The same thing proved to happen in the second stage, namely the arrangement. Syllabus is also a guide in preparing the information to be disseminated. The next step summarizes, the ability of students to make a summary to be posted to the blog can be seen in table 2.

Table 2. Information Summary Stage by Student

\begin{tabular}{ccc}
\hline Summary & $\begin{array}{c}\text { The Number } \\
\text { of }\end{array}$ & \% \\
\hline Posts are summaries & 139 & 49,4662 \\
Post without selection & 142 & 50,5338 \\
Total & $\mathbf{2 8 1}$ & $\mathbf{1 0 0}$ \\
\hline
\end{tabular}

Based on table 2. However $49.5 \%$ posted the reading result in the form of summary and $50.5 \%$ post without selection. Regarding the use of blog folios, obtained data as follows:

Table 3. Use of Blog folio in Blended Learning

\begin{tabular}{clcc}
\hline \multirow{2}{*}{ Motivation } & \multicolumn{1}{c}{ Item } & $\begin{array}{c}\text { The Number } \\
\text { of }\end{array}$ & \% \\
& Motivated to report readings to the blog & 144 & 82,28571 \\
& Visitor comments increase motivation & 115 & 65,71429 \\
& Reading other students' posts & 114 & 65,14286 \\
Active participation & Leave comments on blogs that are read & 71 & 40,57143 \\
& Interest to share the reading on the blog & 116 & 66,28571 \\
& Interested in blogs to improve learning & 136 & 77,71429 \\
interest & Interest reporting readings on double folio & 114 & 65,14286 \\
& Feel the benefits of reporting readings to blogs & 139 & 79,42857 \\
& Feel the benefits of blogs to share other posts & 138 & 78,85714 \\
\hline
\end{tabular}


Table 3 shows interest in the activities undertaken during the blog folio. The results of interviews with them also show similar results that they enjoy activities in processing information ranging from finding, processing and spreading information. Students recognize that the use of blog folios is more interesting than the usual way of collecting weekly readings that are directly directed to the lecturer. "Posting weekly readings on blogs allows us to visit and comment on other posts," one student said. These benefits are felt because they are motivated, participate actively and are interested in the use of blogs.

Universitas Negeri Padang has been equipped with free internet service for students. Many things have been done in optimizing the facilities that have been available, including e-learning, online learning, blended learning and mobile learning. In the previous semester, students have had a blog as one of the lecture achievements. In this semester, through this research (January-June 2017), the researcher did not ignore what students have and with the goal of optimizing the campus facilities, asking students to report their weekly reading through the blog. Blogs is as a means of communication of lecturers-students and students in realizing learning communication in a blended learning environment. At the beginning of lectures lecturers inform the step of information processing presented on the blog in the digital age. The move adapted the elaboration theory of Reigeluth, Merrill, Wilson, \& Spiller (1994), is sequencing, synthesizing, and summarizing. Although reading reports weekly have been posted on each student's blog and learning communication is formed, this class does blended learning while maintaining face-toface meetings in the classroom. Material mastery formulation $40: 60,40 \%$ at face-toface meetings and 60 percent through virtual interaction. Therefore, researchers apply blended learning with the use of blog folio. The results showed that the use of blog folio in blended learning provides benefits to the ability of students to process information. Students who are actively developing blogs and improving the content inside them find their skills growing. The use of blog folio is done because it should be done lecture innovation. The trend of the use of blogs as a medium in learning and learning increases rapidly every day (Goktas and Demirel, 2012). The use of blog folio can't be separated from the opinion of Watkins \& Corry (2011) that the portfolio online (eportfolio) increasingly become a means to show the expertise, experience and achievement of college students.

Blogs as e-portfolios are rated well by students, but aspects of information selection need to be improved. Students have a tendency to utilize the source of the internet rather than reading a printed book. From the process that has been done, and when you want to continue learning innovation by optimizing blog folio in blended learning can follow the advice of Watkins and Corry (2011) before creating a portfolio need 1) review the guidelines, 2) examine sample portfolios, 3) create a "look-n-feel", 4) confine that you have access to software, 5) identify any additional hardware Requirements, 6) confirm adequate storage space for the collage's server, 7) Ask for help in creating WebPages. Next, the portfolio should be 1) Back Up Files, 2) Follow Through with Your "Look-n-Feel", 3) Develop a Structure for Linking WebPages, 4) Review Grading Criteria and after making portfolio 1) Keep a Record, 2) Review the Submission Requirements, 3) Improve Your Performance (Watkins and Corry, 2011). The interesting thing about the use of blog folios by students is from the previous reading reports weekly is not only read by lecturers, in this study anyone who is connected to the internet and visit the blog pages can read, comment, and create a discussion, so as to create relative learning interactivity high. Such activities become the motivation for the students and encourage them to be more careful and present the writing with a more interesting style. 


\section{CONCLUSION AND RECOMMENDATION}

Blog folio in blended learning contributes to information processing skills. The use of blogs by students as an e-portfolio provides an opportunity for them to be actively involved in information processing. Related talks at the beginning, the paradigm of the XXI century, learning and innovation. These three aspects need to be synchronized so that the learning done is useful and meet the demands of the society of the XXI century. So, do not overlook one of them because they all contribute to the future.

\section{REFERENCES}

Beetham, H., \& Sharpe, R. (2013). Rethinking pedagogy for a digital age: Designing for 21 st century learning. routledge.

Brooks, D. W., Nolan, D. E., \& Gallagher, S. M. (2006). Web-teaching: A guide to designing interactive teaching for the World Wide Web (Vol. 9). Springer Science \& Business Media.

Bullock, A. A., \& Hawk, P. P. (2001). Developing a teaching portfolio: A guide for preservice and practicing teachers (Vol. 123). Merrill Prentice Hall Upper Saddle River, NJ.

Collis, B., \& Moonen, J. (2012). Flexible learning in a digital world: Experiences and expectations. Routledge.

Curran, V. R., Sharpe, D., Forristall, J., \& Flynn, K. (2008). Student satisfaction and perceptions of small group process in case-based interprofessional learning. Medical Teacher, 30(4), 431-433.

Desimone, L. M. (2009). Improving impact studies of teachers' professional development: Toward better conceptualizations and measures. Educational Researcher, 38(3), 181199.
Duzenli, H. (2018). Teaching in a digital age: Guidelines for designing teaching and learning for a digital age. Turkish Online Journal of Distance Education, 19(2), 218-219.

Dziuban, C., Moskal, P., \& Hartman, J. (2005). Higher education, blended learning, and the generations: Knowledge is power: No more. Elements of Quality Online Education: Engaging Communities. Needham, MA: Sloan Center for Online Education, 88-89.

Feiman-Nemser, S. (2003). What new teachers need to learn. Educational Leadership, 60(8), 25-29.

Fullwood, C., Sheehan, N., \& Nicholls, W. (2009). Blog function revisited: A content analysis of MySpace blogs. CyberPsychology \& Behavior, 12(6), 685-689.

Gatlin, L., \& Jacob, S. (2002). Standardsbased digital portfolios: A component of authentic assessment for preservice teachers. Action in Teacher Education, 23(4), 35-42.

Goktas, Y., \& Demirel, T. (2012). Blogenhanced ICT courses: Examining their effects on prospective teachers' ICT competencies and perceptions. Computers \& Education, 58(3), 908917.

Guskey, T. R. (2002a). Does it make a difference? Evaluating professional development. Educational Leadership, $59(6), 45$.

Guskey, T. R. (2002b). Professional development and teacher change. Teachers and Teaching, 8(3), 381391.

Harasim, L. (2012). Learning theory and online technologies. Routledge.

Hartnell-Young, E., \& Morriss, M. (1999). Digital professional portfolios for change. Hawker Brownlow Education. 
Inan, F. A., \& Lowther, D. L. (2010). Factors affecting technology integration in $\mathrm{K}$ 12 classrooms: A path model. Educational Technology Research and Development, 58(2), 137-154.

Jacobs, H. H. (2010). Curriculum 21: Essential education for a changing world. ASCD.

Kuo, Y.-C., Belland, B. R., \& Kuo, Y.-T. (2017). Learning through blogging: students' perspectives in collaborative blog-enhanced learning communities. Journal of Educational Technology \& Society, 20(2), 37-50.

Land, S. M., \& Greene, B. A. (2000). Projectbased learning with the World Wide Web: A qualitative study of resource integration. Educational Technology Research and Development, 48(1), 45-66.

Li, K., Bado, N., Smith, J., \& Moore, D. (2013). Blogging for teaching and learning: An examination of experience, attitudes, and levels of thinking. Contemporary Educational Technology, 4(3), 172-186.

Mayer, R. E., \& Alexander, P. A. (2016). Handbook of research on learning and instruction. Taylor \& Francis.

Niguidula, D. (2010). Digital portfolios and curriculum maps: Linking teacher and student work. Curriculum, 21, 133152.

Papastergiou, M., Gerodimos, V., \& Antoniou, P. (2011). Multimedia blogging in physical education: Effects on student knowledge and ICT self-efficacy. Computers \& Education, 57(3), 1998-2010.

Põldoja, H., \& Laanpere, M. (2014). Exploring the potential of open badges in blog-based university courses. In
International Conference on WebBased Learning (pp. 172-178). Springer.

Pritchard, A. (2013). Ways of learning: Learning theories and learning styles in the classroom. Routledge.

Reigeluth, M. C., Merrill, D. M., Wilson, G. B., \& Spiller, T. R. (1994). The Elaboration Theory of Instruction: A Model for Sequencing and Synthesizing Instruction, Instruction Design Theory. Educational Technology Publications. Englewood Cliffs, New Jersey.

Rose, D. H., Meyer, A., Strangman, N., \& Rappolt, G. (2002). Teaching every student in the digital age: Universal design for learning.

Sari, M. (2014). The use of facebook in blended course in teacher training college. Al-Ta Lim Journal, 21(2), 145-153.

Smaldino, S. E., Lowther, D. L., Russell, J. D., \& Mims, C. (2008). Instructional technology and media for learning.

Tur, G., \& Urbina, S. (2014). Blogs as Eportfolio Platforms in teacher education: affordances and limitations derived from student teachers' perceptions and performance on their Eportfolios. Digital Education Review, 26, 1-23.

Wall, K., Higgins, S., Miller, J., \& Packard, N. (2006). Developing digital portfolios: Investigating how digital portfolios can facilitate pupil talk about learning. Technology, Pedagogy and Education, 15(3), 261-273.

Watkins, R., \& Corry, M. (2011). E-learning companion. A Student's Guide to Online Success, Cengage Learning, USA, 45. 